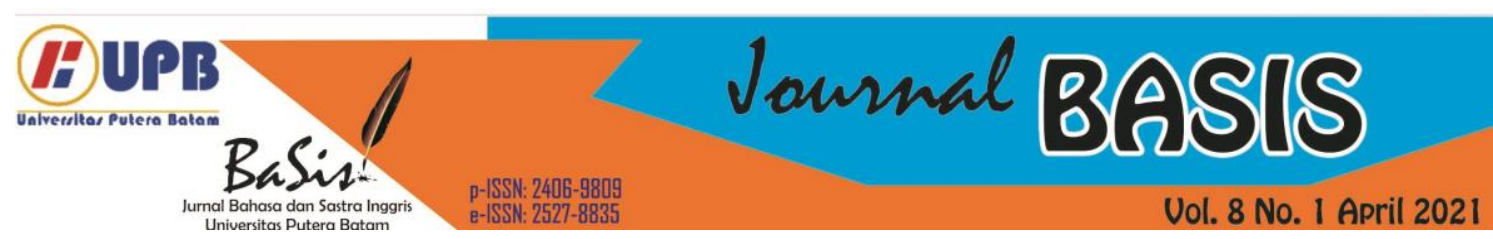

\title{
POSITIVE POLITENESS IN “OPRAH'S 2020 VISION TOUR": HOW REASONS AND FACTORS INFLUENCED THE CHOOSING OF STRATEGY
}

\author{
Anda Damayanti ${ }^{1}$ \\ Universitas Putera Batam (UPB), Batam, Indonesia \\ pb171210014@upbatam.ac.id \\ Zia Hisni Mubarak ${ }^{2}$ \\ Universitas Putera Batam (UPB), Batam, Indonesia \\ zia.hisni@puterabatam.ac.id
}

\begin{abstract}
Politeness can be said to be very sensitive interpersonal act carried out by someone in the form of a threat of the acting politely or not. Positive politeness influence greatly influence the attitudes and behaviors carried out by someone. Attitudes and behaviors in positive politeness were reflection of a person's character to be good or not to others. The aimed of this research is to give an example in order to prioritize using positive politeness when speaking in any situations, including talk show. The data were taken from the utterances in every conversation that Oprah Winfrey said with her guests. Conversation data was transcribed into written data. And analyzed qualitatively based on conversations between Oprah Winfrey and her guest Michelle Obama in Oprah's 2020 Vision Tour Talk Show. The positive politeness strategy aims to minimize the distance between Oprah Winfrey and her guests which expected to create a sense of comfort when talking on the talk show. There are 8 strategies found in this data that categorized as positive politeness, they are: Exaggerate (interest, approval, sympathy with hearer), intensify interest to the hearer, seek agreement (to find and try to approval by the opponent said), avoid disagreement, presuppose/rise/assert common ground, joke (make a joke), be optimistic, include both the speaker and the hearer in the activity, and give (or ask for) reason. This research also found that payoff and circumstances become factor on why the speaker uses certain positive politeness strategy. Circumstances which are found in this research are relative power and social distance.
\end{abstract}

Keywords: Interlocutor, Oprah Winfrey, Positive Politeness Strategy, Talk Show

\section{INTRODUCTION}

The talk show features one or several people discussing a particular topic which led by a host. There is a special feature of a talk show that sets it apart from other television shows. According to Timberg \& Erler (2002), a talk show centered on the host, conversation is experienced in its present form, spontaneous but highly structured, commodity pro ducts, stirred in strict formulas and measurable segments of expensive network time, and designed for aerial topics that are appeal to as many audiences as possible.

There are many television shows besides talk shows which have greatly overturned politeness. Television provides information which can be watched by all ages, including minors. An example of the show that risque is comedy television entertainment shows, in these shows it does confirm that jokes delivered with secures jokes, but many also sometimes tucked into obscene 
words that were not censored and still aired on purpose. Another example is in music shows. Many lyrics in the songs use rude words such as "bullshit, fuck you, bitch". From the existing phenomenon, researchers conducted a positive politeness strategy research with the object of study is Oprah's 2020 vision tour talk show. The talk show led by Oprah Winfrey which tends to be more serious when discussing something so that it also affects the style of the conversation. In talk show hosted by Oprah Winfrey, there are more positive politeness applied by the speaker for both questioning and answering. The positive politeness strategy used both by the host and by the guest.

From the above consideration, researchers focused on positive politeness strategies used, reasons and factors that influence the choice of using the strategy used by Oprah Winfrey in her talk show to be analyzed. This research aiming to replace impolite words with more polite words, with an example from Oprah Winfrey's conversation with her guests who put a very high priority on positive politeness when speaking.

\section{LITERATURE REVIEW}

According to Holtgraves (2010), politeness can reflect a good attitude is when someone knows how to arrange talks and be polite to others like someone

older, coworkers, customers, bosses or whoever it is to be a good value for the character of someone who applies an example of strategy good politeness. Whereas an example of someone who is not good enough and who does not implement a politeness strategy cannot do the same thing as someone who applies a good politeness strategy.
Brown \& Levinson (1987) state that there are several speech acts that can threaten another person's face; that familiar with the term Face Threatening Acts. It is known as bald on record, negative politeness, positive politeness and bald of record as the type of politeness strategy for sake of reducing the FTAs.

Positive politeness is categorized into fifteen strategies by (Brown \& Levinson, 1987), which are: notice, attend to hearer (his interest, wants, needs, goods); exaggerate (interest, approval, sympathy with hearer); intensify interest to the hearer; use ingroup identity markers; seek agreement; avoid disagreement; presuppose/rise/assert common ground; joke; assert or presuppose speaker's knowledge and concern for the hearer's wants and willingness to fit one's own wants with them; offer, promise; be optimistic; include both the speaker and the hearer in the activity; give (or ask for) reason; assume or assert reciprocity; give gift to the hearer (goods, sympathy, understanding, cooperation).

The use of politeness strategies also influenced by several factors, according to Brown \& Levinson (1987:71), there are two factors that influence the choice of strategy: the payoffs and relevant circumstances. The payoffs happened when speakers who use positive politeness strategies in their speech and also can limit FTAs by making sure listeners think that they are wanted and thus fulfill what listeners want. While relevant circumstances: the influence of conditions, sociological factors, and determines the level of politeness.

There are some researches that give much inspiration developing this idea. There of them are analyzed by Suryani (2016) about Request strategies based on gender perspective, Aldriani (2019) about The euphemistic expressions in 
newspaper, Suryani (2019) about Impolite responses to donald trump's posts, and Alvina (2019) about politeness in learning the Education Profession. Beside that, this research has its own unieqness reseach that different with those previous reseach by focusing in Oprah as source data.

\section{RESEARCH METHOD}

This research used descriptive qualitative approach. The method used in analyzing data were qualitative based on Creswell (2014) which explained event using words, sentences, and paragraphs in a text that can be interpreted and understood to get concept about certain interesting phenomena. Object of this research is positive politeness strategy from talk show where it is downloaded from YouTube (Subroto, 1992). The data of this research were the conversations which happen in the talk show entitled Oprah's 2020 Vision Tour Talk Show in the episode which Michelle Obama is the guest of the talk show. Researchers took following steps in conducting data analysis; watching the talk show, replaying the talk show to understand the whole story, written into transcript, underline and analyzing the sentence that contain the positive politeness strategy. Researchers analyzed the positive politeness by dividing them into several strategies.

\section{RESULT AND DISCUSSION}

\subsection{Result}

This section shows the frequency of positive politeness strategies used in selected interviews. The table below shows the frequency and total of positive politeness strategies used by Oprah and Michelle Obama as guests. The findings show that Oprah and her guests use positive politeness strategies in 8 of the 15 strategies proposed by (Brown \& Levinson, 1987).
Table 1. Data Findings

\begin{tabular}{lc}
\hline \multicolumn{1}{c}{ Strategy } & Frequency \\
\hline Exaggerate & 2 \\
Intensify interest & 2 \\
to hearer &
\end{tabular}

\begin{tabular}{|c|c|}
\hline Seek agreement & 2 \\
\hline $\begin{array}{l}\text { Avoid } \\
\text { disagreement }\end{array}$ & 1 \\
\hline $\begin{array}{l}\text { Presuppose/raise/ } \\
\text { assert common } \\
\text { ground }\end{array}$ & 1 \\
\hline Jokes & 1 \\
\hline $\begin{array}{l}\text { Include both } S \\
\text { and } H \text { in the } \\
\text { activity }\end{array}$ & 1 \\
\hline Be optimistic & 1 \\
\hline Total & 11 \\
\hline
\end{tabular}

From table above, it can be seen that there are 8 strategies that used by speaker and hearer in the talk show. The most frequent strategy by the speaker and hearer is exaggerate, intensify interest to hearer and seek agreement.

\subsection{Discussion}

As researchers mentioned in literature review chapter, researchers employs (Brown \& Levinson, 1987) strategies of positive politeness. They stated that positive politeness divided into 15 strategies. Here some repetition on the dialogue based on understanding of positive politeness.

\section{Exaggerate (interest, approval, sympathy with $\mathbf{H}$ )}

This strategy can be found within the utterance which the intonation and stress is exaggerate. When the utterances indicating some interest, approval and sympathy it can be conclude into this category.

\section{Data 1:}

Oprah Winfrey: "I think it's like now eleven point seven million probably 
twelve since we've been sitting here billion what it says to me is that it's such an extraordinary time to be a strong confident assured and above all else well a woman in the world today"

The example above is classified as the positive politeness strategy in exaggerate interest, the utterance above Oprah Winfrey as the host emphasized how Michelle's book is widely known and many people already had the book. Oprah said that the book is sold by millions of people although we don't know exactly if it is true or not. Oprah also said implicitly that Michelle is a strong and confident woman makes a best-selling book in a such extraordinary time. She used this strategy to show her interest and good intention for Michelle and her achievement. It is shown that Michelle has a big interest from Oprah.

\section{Data 2:}

Oprah Winfrey: "white house where you have access to everything and everybody in the world"

The second example in strategy which is exaggerates interest also done by the host, Oprah Winfrey. Here, Oprah show interest in Michelle live. As we know Michelle is a past first lady of America so that she lives in White House. Oprah exaggerate her vision of white house on how they can access everything and everybody in the world if people live in White House. The utterance shows that Oprah put interest in Michelle not only about herself but also about her family and her future.

\section{Intensify interest to hearer}

This strategy occurred when the speaker emphasized their desire to the listener in certain way of communication. It is so that the speaker can intensify their interest in the conversation or to make a great story.

\section{Data 3:}

Oprah Winfrey: "Oh, so when I started thinking about who has had some of the greatest impact on the global vision of what health and wellness and empowerment looks like this person's name came to mind first Brooklyn please welcome our WW 2020 visionary conversation before the first lady of the United States."

This utterance takes place in the first line when Oprah as the guest wants to welcome Michelle in front of the audience. In the utterance "the greatest impact on the global vision of what health and wellness and empowerment looks like this person's name came to mind first", Oprah used this strategy because she wanted to draw audience attention to her guest which is Michelle Obama so that they can get a good appreciation and applause by expressing the fact dramatically.

\section{Data 4:}

Oprah Winfrey: "yeah I was going to ask you that because you know when you are the rock star that you are and yes when you're filling stadiums all over the world you're a rock star just take it just take it"

This utterance is indicated as strategy of intensify interest, though she directly say the utterance to Michelle but we can see in here Oprah more like communicated to her audience so that it can intensify the audience's interest to the fact on how Michelle is like a rock star when she filling stadiums all over the world when she was making speech. 


\section{Seek agreement}

Brown \& Levinson (1987) indicating seek agreement into two ways which are safe topics and repetition. When it comes with those two it can be seen that the speaker claiming common ground with the listener so that it seems that they agree with him/her.

\section{Data 5:}

Oprah Winfrey: “It's just thing when you wear a pair of boots like that, it's really like they go to the Michelle Museum that's right"

Here, strategy is applied in their conversation when Oprah agreeing on what Michelle said by repeating and adding something interesting on what the speaker said in the conversation, perhaps to emphasize emotional with the utterance (to emphasize the interest and surprise).

\section{Data 6:}

Oprah Winfrey: "But does this feel familiar"

Oprah Winfrey: "So, I know 2019 your year or what?"

In this example of strategy of seek agreement, Oprah as the speaker employ a "safe topic" as a seek agreement strategy. This utterance indicating that the speaker, which is Oprah, emphasize her statement in the form of question seeking agreement on what Oprah thinks whether 2019 is Michelle year or not.

\section{Avoid disagreement}

Token agreement, pseudo agreement, white lies, and hedging opinion is the four ways of Avoid disagreement.

Data 7:

Oprah Winfrey: "No, you don't, you just started to go something"

Michelle Obama: "right?"

Those two utterance above are indicates using strategy avoid disagreement with token agreement as the way the speaker employs positive politeness strategy. The utterance belongs to token agreement because the speaker actually agree with what the hearer said.

\section{Presuppose/raise/assert common ground}

In this strategy it will be easier known as gossip or small talk. It is a way to make a topic of conversation when the speaker talking about topic which are not related to be heard for a while.

\section{Data 8:}

Oprah Winfrey: "what's the best advice do you think you've given your daughters?"

Michelle Obama: "oh gosh I give them so much advice they're so sick of me, you know now that they're in college"

This conversation takes place when both of them talking about Michelle personal life. Her family life is basically all over the television knowing she is a public figure as a first lady. So, it is common knowledge that people know about her daughters being in the college. Here in the utterance Michelle talks about her daughter which already in the college that maybe people already know but she is emphasized that fact so that it matches on following answer of Oprah's question.

\section{Jokes}

In the effort of reducing the size of FTA, the speaker can be use joke as the strategy of positive politeness. Joke itself used in many ways of strategies speaking as the way of breaking the ice of the conversation so that the listener is comfortable with the way the conversation going.

\section{Data 9:}


Oprah Winfrey: "I know, all of the people in this room paid money to come out to give up a Saturday we know all that Saturday mean" Michelle Obama: "as I said ain't nobody twerking on this stage."

This utterance is classified as a joke because Michelle is being agreed by what Oprah said that people need to connect to other people. Being there in Oprah Show is one of the ways to connect with people. Oprah Show takes time on Saturday and the audiences spent their Saturday watching Oprah Show even though Saturday is a weekend where people usually spent time with family or take rest. Michelle agreeing on that statement by joking that no one twerking in the stage but people still continue watching that shows how much human need to connect. The jokes here take place as the agreement also to puts listener on comfortable situation.

\section{Be optimistic}

In this strategy, the speaker's mind is that the listener wants to do something for him/her and vice versa. Then help the speaker to obtain the objectives because it would be useful to do something together.

\section{Data 10:}

Michelle Obama: "you know my husband was busy being president so I don't think he understood how much time and energy"

Oprah Winfrey: "don't we wish"

Michelle Obama: "right?"

This utterance can be classified as strategy by (Brown \& Levinson, 1987) which is be optimistic because the context of the conversation. Here, Oprah as the host asked Michelle on how she deals with the parenting of her 2 daughters. Michelle then said that it takes a lot of energies both physical and emotional. Michelle also stated that his husband, which is at that moment is President of United States, can not understand how she feels of dealing with her daughters because of his business. Here, the utterance that implicate of Obama being a president triggered Oprah in a good way. What it means by triggered is how they wished that Obama become a president again, it can be seen from the utterance "don't we wish". Means that Oprah want Obama to become President of United States again.

\section{Include both $S$ and $H$ in the activity}

This strategy often uses the word "we" or "let's" to express a situation. The strategy often used both words so that it can makes the listener feels included in the activity.

\section{Data 11:}

Michelle Obama: "we feel lonely and when we come together in a space like this you know for whatever the reason whether it's to hear about a book or to talk about health or to see Oprah it reminds us that we are not"

When Michelle as a speaker uses "we" it is including both of them to the conversation. When Michelle stated the utterance, she included herself and also both Oprah and the audience as the hearer as "we". It is the way of the speaker to include both of the speaker itself and hearer in the activity. What it means by activity in here is the object of the conversation which is how nowadays people tend to feel lonely and need to connect with other people.

\section{The reason of how Positive Politeness applied in the Oprah Winfrey Show}


According to Hymes (1974), theory of speaking emphasized on the context of the talk show. It helps the readers understanding what influence the speaker of using positive politeness and reason why they using it. In this section, researchers described the setting and scene, the participants involved in the conversation, the goal, act sequence, key, instrumentalities, norms and the genre of the conversation.

Setting and: The setting of this Scene

Participants : friendly. relationship between Michelle Obama and Oprah Winfrey, become two powerful female influences on Barack Obama's presidency, is quite close. Both of them is in the same side in political view and has been friend for long time.

Ends : The overall end of this show is talking about what has happened in Michelle life. What her upcoming vision and his spouse which the former president Barrack Obama, also about the family and their children. They also talking about the current book which Michelle wrote also her personal life and her motivation.

Act : Both of them talking sequence with an informal and friendly word for expressing the content or answer of the question asked by the host. The content of this show is basically question and answer with little bit humor here and there.

Key : Key refers to tone, manner, or spirit which speech is carried put. The manner of this show where Oprah and Michelle doing is friendly but still in a serious way.

Instrument : The message delivered here is in an oral form and informal register.

Norms of : Oprah's greeting with Interaction Michelle Obama is showing how she adore and happy to see her again. It can be seen throughout the conversation how Oprah respect Michelle as a writer, wife, mom, and as Michelle herself.

Genre : Friendly conversation

The Factors Influencing the Use of Positive Politeness Strategy Employed in the TV Talk Show Oprah's 2020 Vision Tour with Michelle Obama 
In this research, the employment of positive politeness strategy influenced by two factors which are payoff and circumstance indicates by (Brown \& Levinson, 1987).

\section{Payoff}

By adopting a positive politeness strategy, the speaker can benefit greatly. Speakers will be able to minimize FTA by convincing listeners that they like the listener and want to fulfill the listener's wishes. Thus, the positive face of the listener is not threatened by the speaker.

For example:

Oprah Winfrey: "Oh, so when I started thinking about who has had some of the greatest impact on the global vision of what health and wellness and empowerment looks like this person's name came to mind first, Brooklyn please welcome our WW 2020 visionary conversation before the first lady of the United States".

This strategy is influenced by payoff and circumstances: social distance. Payoff represents that Oprah wants to satisfy Michelle. It is shown here, that Oprah introduce Michelle in front of her audiences so that she intensifies the interest to her Hearer which is Oprah. The second is circumstances. The participants have a close social distance, because they are actually old friends. Both of them already know for quite long time. Oprah already held interview with Michelle Obama as a guest for several times.

\section{Relevant Circumstances}

The degree of seriousness of FTA is also influenced by the circumstances, sociological variables, and thus to a determination of the level of politeness. According to (Brown \&
Levinson, 1987) there are three dimensions to determine the level of politeness; they are relative power $(\mathrm{P})$, social distance (D) and size of imposition (R).

\section{a. Relative Power}

Usually, people using Power $(\mathrm{P})$ in everyday life is when the interlocutor is people which having greater power or authority over the speaker. It is very rare people using Power (P) with those who do not have authority or greater power. We can easily find this kind of hierarchy Power when in the formal field such as in the courts, the military and workplace.

For example:

\begin{abstract}
Michelle Obama: "we feel lonely and when we come together in a space like this you know for whatever the reason whether it's to hear about a book or to talk about health or to see Oprah it reminds us that we are not"
\end{abstract}

This strategy is influenced by payoff and circumstances. Concerning with payoff, she wants to satisfy the hearer FTA which are the host and the audiences with included both of them in the conversation topic. That utterance is talking about book which Michelle write, it leads on the second factors namely circumstances, that include social distance and power rating. The social distance between the participants actually is not too close. Because Michelle here speaks as the book writer, so that the social distance is only between author and reader. It also in line with the next factor which is the power rating. The power rating here also shows that they are different; Michelle here act as an author which talking about her book so that she knows everything about her book and the circumstances surrounding the fact 
on why she chooses to do 30 cities tour talking about her book.

\section{b. Social Distance}

Social distance can be seen as a combination of real psychological factors (status, age, sex, degree of intimacy, etc) that together determine the overall level of respect for speech in a given situation. It is based on the symmetric relationship between speaker and listener

For example:

Oprah Winfrey: "How did you do that in the white house where you have access to everything and everybody in the world"

Payoff and circumstances (social distance and the size of imposition) influence this strategy. Payoff explains that Oprah uses this exaggerate interest strategy because she really hopes that Michelle as the hearer feels that Oprah give huge interest in her life. The second is circumstances that include is social distance and also the size of imposition. The social distance between the participants here shows that the status is different. In this question, Oprah as the host asking question to Michelle not as an author of her book but as The First Lady of America which lived in White House while raising her children. So, it is appropriate if Oprah use that strategy to show the social distance between First Lady and ordinary society.

\section{CONCLUSION}

After analyzing data based on the problem statements, the conclusion is drawn as follows; this research found 8 strategies from 15 strategies stated by (Brown \& Levinson, 1987). This research found that the reasons why the participant employs certain positive politeness are analyzed based on the speaker's purposes in pronouncing positive politeness. The contexts that influences the choice of positive politeness strategies used in talk show were the relationship between the speaker and the hearer; the ends of the conversation; the setting of the conversation; and the key of the conversation. Another factor influencing the speaker on using certain positive politeness strategy are the payoff and relevant circumstances. Here in this research the relevant circumstances that found are relative power and social distance. Although Michelle Obama as the guest is former first lady of America, but Oprah and Michelle are an old friend. Oprah also already interviewed Michelle for several time on her show. It can be shown on this research that between guest and the host social distance is close. But, at some point there is question asked by Oprah regarding Michelle as an author or regarding Michelle when she was still in the white house, it makes the power of the speaker becomes another factor influencing Oprah as the host to use certain strategy of positive politeness.

\section{REFERENCES}

Aldriani, Y. (2019). Euphemistic Expressions Of The Late Princess Lady Diana Marriage Life On The Online Newspaper. IdeBahasa, 1(1), 19-30. Retrieved from https://jurnal.idebahasa.or.id/index.php/ Idebahasa/article/view/2

Alvina, T.S. (2019). Kesantunan Berbahasa Dalam Diskusi Mahasiswa Dan Relevansinya Terhadap Pembelajaran Profesi Kependidikan Di Fkip Uhn Pematangsiantar. IdeBahasa, 1(1), 6576. Retrieved from 
https://jurnal.idebahasa.or.id/index.php/ Idebahasa/article/view/9

Brown \& Levinson, S. (1987). Politeness ( Brown and Levinson 1987 ). Reading.

Creswell, J. W. (2014). Research Design: Qualitative, Quantitative and Mixed Methods Approaches (Fourth). SAGE Publications.

Edi, S. (1992). Pengantar Metode Penelitian Lingustik Struktural. Surakarta: Surakarta: Sebelas Maret Univeritas Pres.

Holtgraves, T. (2010). Social psychology and language: words, utterances, and conversation.

https://doi.org/10.1002/978047056111 9. socpsy002036

Hymes, D. H. (1974). Foundations in sociolinguistics: an ethnographic approach. Philadelphia, PA: University of Pennsylvania Press.

Timberg, B. M., \& Erler, R. J. (2002). TALK: A History of the TV Talk Show (First). Library of congress cataloging.

Surayni, Melly Siska. 2021. STRATEGI PERMINTAAN DALAM BAHASA MINANGKABAU: TINJAUAN DARI PERSPEKTIF JENDER. JURNAL BASIS, [S.1.], v. 3, n. 1, p. 64-75, apr. 2016. ISSN 2527-8835. Available at: <http://ejournal.upbatam.ac.id/index.ph p/basis/article/view/493>

Surayani, Melly Siska. (2016).Strategi Permintaan Dalam Bahasa Minangkabau: Tinjauan Dari Perspektif Jender. Jurnal Basis, [S.1.], v. 3, n. 1, p. 64-75, apr. 2016. ISSN 2527-8835. Available at: <http://ejournal.upbatam.ac.id/index.ph p/basis/article/view/493

Suryani, M. S. (2019). Impolite Responses To Donald Trump's Posts On Instagram. IdeBahasa, 1(1), 77-84. Retrieved from https://jurnal.idebahasa.or.id/index.php /Idebahasa/article/view/7 